\title{
First TMEM126A missense mutation in an Italian proband with optic atrophy and deafness
}

Chiara La Morgia, MD, PhD, * Leonardo Caporali, ScD, PhD, * Francesca Tagliavini, ScD, PhD, Flavia Palombo, ScD, PhD, Michele Carbonelli, MD, Rocco Liguori, MD, Piero Barboni, MD, and Valerio Carelli, MD, PhD

Neurol Genet 2019;5:e329. doi:10.1212/NXG.0000000000000329

Recessively inherited optic neuropathy has been an elusive entity for a long time. Currently, a few causative genes have been described, ${ }^{1-6}$ associated with a spectrum of isolated or syndromic optic atrophy. Among these genes, TMEM126A (OPA7) was the first to be reported, with a single causative mutation found in all pedigrees identified to date of North African ancestry (c.163C $>\mathrm{T}$; p.Arg55X), thus possibly belonging to the same founder mutational event. ${ }^{1,7,8}$

\section{Case report}

A 16-year-old girl was born by likely consanguineous parents (figure A). Delivery was uneventful, and psychomotor development was normal. Medical history was relevant for an isolated febrile seizure at 4 months and migraine since age 14 years. The only brother presents a mild language disorder improved by logopedic rehabilitation, and the grand-grandmother is affected by epilepsy.

Visual problems were recognized when the patient was aged 4 years with evidence of bilateral optic atrophy. We observed the patient at age 16 years. Neurologic examination was unremarkable except for the presence of sporadic postural and rest myoclonic jerks at upper and lower limbs and brisk deep tendon reflexes. Ophthalmologic evaluation showed visual acuity OD 0.16 , OS 0.125 , bilateral temporal pallor at fundus examination, profound color deficit, and bilateral cecocentral scotoma at automated visual fields (figure B). Optical coherence tomography showed bilateral diffuse optic atrophy (figure B).

Laboratory examinations were relevant for the presence of increased lactic acid levels after standardized exercise ( $35.5 \mathrm{mg} / \mathrm{dL}$; normal values $5-22 \mathrm{mg} / \mathrm{dL}$ ). Brain MRI was normal. Cardiologic examination showed only the presence of a mild mitral valve prolapse. Audiometry disclosed the presence of bilateral mild sensorineural deafness. EMG ruled out the presence of peripheral neuropathy. Pattern visual evoked potentials showed the absence of cortical responses in OD and increased latency in OS. Somatosensory evoked potentials and EEG with muscle recordings were normal and in particular did not reveal the presence of a cortical correlate of myoclonic jerks. Cognitive evaluation showed a profile within normal limits (Wechsler Intelligence Scale for Children-IV score $=88$ ).

Genetic analysis, after informed consent and EC approval (CE AVEC 211/2018), by a custom next-generation sequencing (NGS) panel of optic atrophy-related genes revealed the presence of a homozygous mutation affecting the TMEM126A gene (c.497A>G, p.Q166R), affecting one of the transmembrane helices. According to the public database GnomAD

\author{
Correspondence \\ Dr. La Morgia \\ chiara.lamorgia@unibo.it
}

\footnotetext{
*These authors contributed equally to the manuscript.

From the IRCCS Istituto delle Scienze Neurologiche di Bologna (C.L.M., L.C., F.T., F.P., M.C., R.L., V.C.), UOC Clinica Neurologica; Dipartimento di Scienze Biomediche e Neuromotorie (C.L.M., R.L., V.C.), Università di Bologna; and Studio Oculistico d'Azeglio (P.B.), Bologna, Italy.

Funding information and disclosures are provided at the end of the article. Full disclosure form information provided by the authors is available with the full text of this article at Neurology.org/NG

The Article Processing Charge was funded by the authors.

This is an open access article distributed under the terms of the Creative Commons Attribution-NonCommercial-NoDerivatives License 4.0 (CC BY-NC-ND), which permits downloading and sharing the work provided it is properly cited. The work cannot be changed in any way or used commercially without permission from the journal.
} 

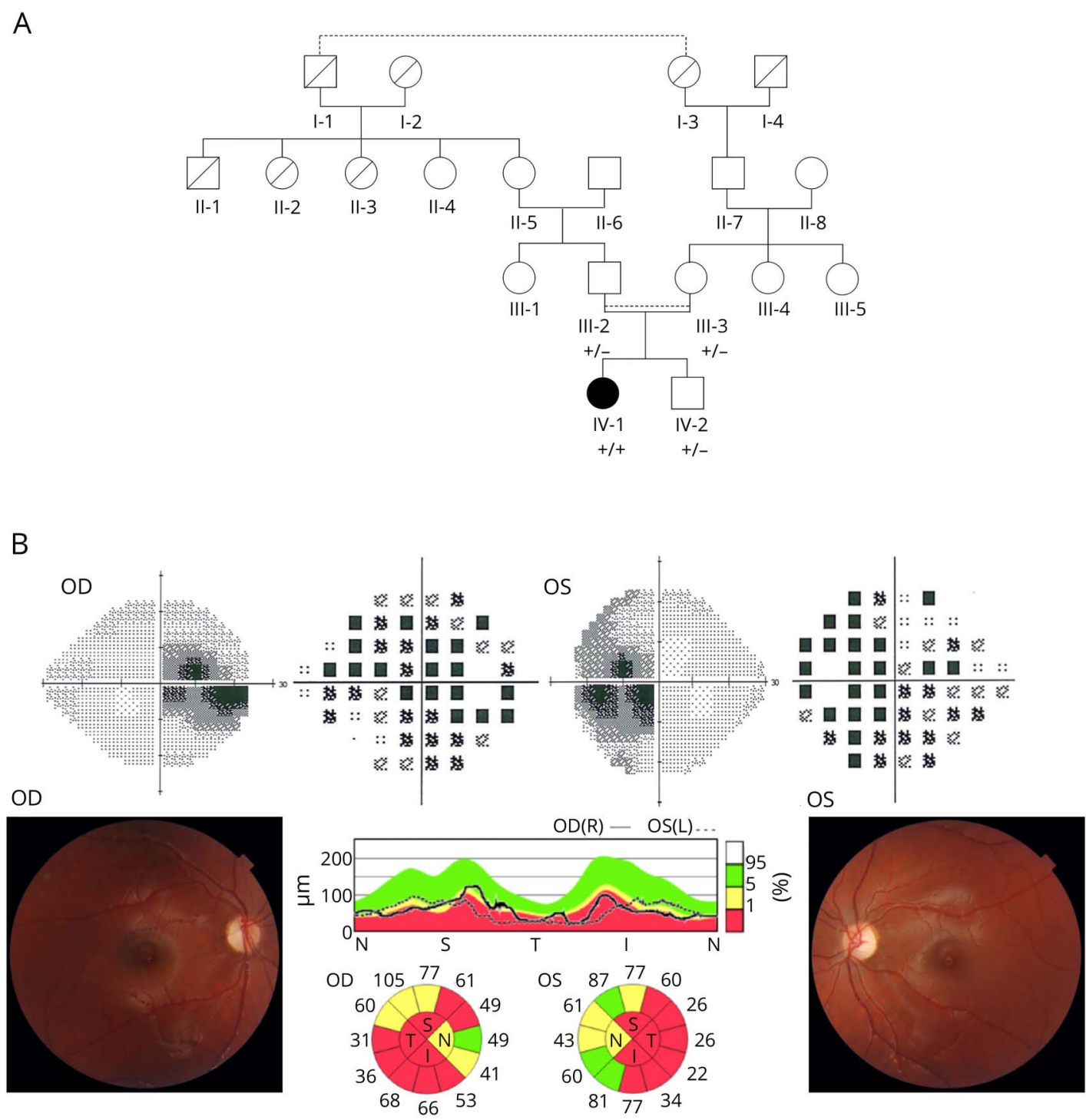

(A) The pedigree and the segregation of the pathogenic TMEM126A mutation c.497A>G, p.Q166R, confirmed by Sanger sequencing, are shown. As shown by the reconstructed pedigree, maternal grand-grandmother and paternal grand-grandfather carried the same family name, both originating from a small village in Sicily, thus strongly suggesting consanguinity and a common founder for the homozygous mutation found in the proband. (B) Ophthalmologic findings: In the upper panel, Humphrey visual fields showed bilateral central scotoma, and in the lower panel, fundus oculi revealed diffuse (more temporally) optic disc pallor, as reflected by the OCT measurements, displaying a generalized reduction of RNFL thickness, more pronounced on the temporal-inferior quadrants.

(gnomad.broadinstitute.org), this variant is reported in 3 alleles, but never in homozygosity, and it is predicted to be pathogenic (CADD phred 26.2). This mutation is compatible with the diagnosis of recessive optic neuropathy (figure A).

\section{Discussion}

The genetic landscape of inherited optic neuropathies, including the rare recessive forms, has been greatly expanding thanks to the availability of NGS techniques. ${ }^{1-6}$ Our case is a non-African patient carrying a recessive homozygous TMEM126A missense mutation, born from likely consanguineous Italian parents and presenting in early childhood with isolated bilateral optic atrophy. Both in silico predictions and segregation analysis were compatible with the diagnosis of recessive optic neuropathy associated with this TMEM126A missense variant. Careful clinical evaluation disclosed also a mild sensorineural deafness, which has been previously reported in association with the North African TMEM126A mutation. ${ }^{1}$ Only 6 families of African ancestry (Algeria and Morocco) have been reported to date, all carrying the c.163C $>\mathrm{T}$ ( $\mathrm{p}$.Arg55X) mutation, suggesting a founder effect. ${ }^{1,7,8}$ The patients described in these reports presented a variable phenotype, despite the association with the same mutation, ranging from isolated to syndromic optic atrophy. Extraocular features included sensorineural deafness, hypertrophic cardiomyopathy, and peripheral polyneuropathy. Moreover, a Leber's hereditary optic neuropathylike presentation has been described in 1 patient. ${ }^{8}$ 
TMEM126A is a mitochondrial protein, located in the inner mitochondrial membrane with still unknown functions, ${ }^{9}$ highly expressed in the brain, cerebellum, fetal brain, skeletal muscle, testis, fetal retinal pigmentary epithelium, and fetal retina of humans. ${ }^{1}$ Polarographic tests and spectrophotometric assays on cultured skin fibroblasts showed normal respiratory chain function, but partial deficiency of complex I in 1 patient from the original study. ${ }^{1}$ In our case, the abnormal lactic acid elevation after standardized effort confirms that TMEM126A is somehow involved in oxidative phosphorylation, even if its precise role remains to be defined and further functional studies are needed.

Overall, we found a second recessive mutation in the TMEM126A gene in an Italian proband, who, similarly to the previously reported cases with the same North African founder mutation, is affected by optic atrophy and mild sensorineural deafness. The phenotype recurring with recessive TMEM126A mutations is quite consistent, and we predict that more cases will be diagnosed, as NGS is now largely available in diagnostic centers.

\section{Author contributions}

C. La Morgia, L. Caporali, and V. Carelli: conception, drafting, and revision of the manuscript. F. Tagliavini and F. Palombo: genetic analysis and interpretation of results. M. Carbonelli and P. Barboni: ophthalmologic evaluation and revision of the manuscript. R. Liguori: interpretation of results and revision of the manuscript.

\section{Study funding}

This study was supported by the Grant GR-2016-02361449 to L.C. and by the "Ricerca Corrente" funding (L.C., F.T., F.P., M.C., and V.C.), both from the Italian Ministry of Health.

\section{Disclosure}

C. La Morgia is involved in clinical trials with Santhera Pharmaceuticals (Raxone in Leber's Hereditary Optic Neuropathy) and GenSight Biologics (gene therapy with GS10 in Leber's Hereditary Optic Neuropathy) and received speaker honoraria for educational courses and travel reimbursements from Santhera Pharmaceuticals. C. La Morgia is funded by the Ministry of Health grant GR-2013-02358026 and is co-PI for the Ministry of Health grant GR-2016-02361449. L. Caporali is funded by the Ministry of Health grant GR-2016-02361449. F. Tagliavini and F. Palombo report no disclosures. M. Carbonelli is involved in clinical trials with Santhera Pharmaceuticals (Raxone in Leber's Hereditary Optic Neuropathy) and GenSight Biologics (gene therapy with GS10 in Leber's
Hereditary Optic Neuropathy) and received travel reimbursements from Santhera Pharmaceuticals. R. Liguori served on the scientific advisory boards of Biogen, Sanofi Genzyme, Argon Healthcare s.r.l., and Editree Eventi s.r.l.; received lecture fees from Dynamicom Education, SIMG Service, Adnkronos Salute unipersonale s.r.l., DOC Congress s.r.l., and First Class s.r.l.; and is a consultant for Alfasigma and Amicus Therapeutics s.r.l. P. Barboni is involved in clinical trials with Santhera Pharmaceuticals (Raxone in Leber's Hereditary Optic Neuropathy) and GenSight Biologics (gene therapy with GS10 in Leber's Hereditary Optic Neuropathy) and received speaker honoraria for educational courses and travel reimbursements from Santhera Pharmaceuticals and Omicron Pharmaceuticals. V. Carelli is involved in clinical trials with Santhera Pharmaceuticals (Raxone in Leber's Hereditary Optic Neuropathy), GenSight Biologics (gene therapy with GS10 in Leber's Hereditary Optic Neuropathy), and Stealth BioPharma (Elamipretide in Primary Mitochondrial Myopathy) and received speaker honoraria for educational courses and travel reimbursements from Santhera Pharmaceuticals. $\mathrm{He}$ is also funded for research program by Stealth Pharmaceuticals, and his research is supported by grants from the Italian Ministry of Health, Telethon, the Emilia Romagna Region, the patient's organization MITOCON, and by private donations. Disclosures available: Neurology.org/NG.

\section{Publication history}

Received by Neurology: Genetics November 16, 2018. Accepted in final form March 5, 2019.

\section{References}

1. Hanein S, Perrault I, Roche O, et al. TMEM126A, encoding a mitochondrial protein, is mutated in autosomal-recessive nonsyndromic optic atrophy. Am J Hum Genet 2009;84:493-498.

2. Angebault C, Guichet PO, Talmat-Amar Y, et al. Recessive mutations in RTN4IP1 cause isolated and syndromic optic neuropathies. Am J Hum Genet 2015;97: 754-760.

3. Metodiev MD, Gerber S, Hubert L, et al. Mutations in the tricarboxylic acid cycle enzyme, aconitase 2, cause either isolated or syndromic optic neuropathy with encephalopathy and cerebellar atrophy. J Med Genet 2014;51:834-838.

4. Hartmann B, Wai T, Hu H, et al. Homozygous YME1L1 mutation causes mitochondriopathy with optic atrophy and mitochondrial network fragmentation. Elife 2016;5:e16078.

5. Inoue $\mathrm{H}$, Tanizawa $\mathrm{Y}$, Wasson $\mathrm{J}$, et al. A gene encoding a transmembrane protein is mutated in patients with diabetes mellitus and optic atrophy (Wolfram syndrome). Nat Genet 1998;20:143-148.

6. Gerber S, Ding MG, Gérard X, et al. Compound heterozygosity for severe and hypomorphic NDUFS2 mutations cause non-syndromic LHON-like optic neuropathy. J Med Genet 2017;54:346-356.

7. Meyer E, Michaelides M, Tee LJ, et al. Nonsense mutation in TMEM126A causing autosomal recessive optic atrophy and auditory neuropathy. Mol Vis 2010;16: 650-664.

8. Désir J, Coppieters F, Van Regemorter N, De Baere E, Abramowicz M, Cordonnier M. TMEM126A mutation in a Moroccan family with autosomal recessive optic atrophy. Mol Vis 2012;18:1849-1857.

9. Hanein S, Garcia M, Fares-Taie L, et al. TMEM126A is a mitochondrial located mRNA (MLR) protein of the mitochondrial inner membrane. Biochim Biophys Acta 2013;1830:3719-3733. 


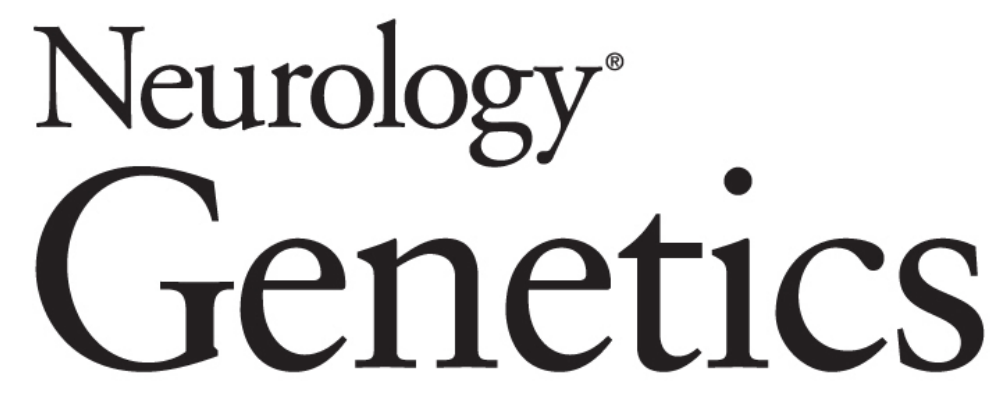

\section{First TMEM126A missense mutation in an Italian proband with optic atrophy and deafness}

Chiara La Morgia, Leonardo Caporali, Francesca Tagliavini, et al. Neurol Genet 2019;5;

DOI 10.1212/NXG.0000000000000329

This information is current as of April 8, 2019

\section{Updated Information \&} Services

References

Citations

Subspecialty Collections

Permissions \& Licensing

Reprints including high resolution figures, can be found at: http://ng.neurology.org/content/5/3/e329.full.html

This article cites 9 articles, 2 of which you can access for free at: http://ng.neurology.org/content/5/3/e329.full.html\#\#ref-list-1

This article has been cited by 1 HighWire-hosted articles: http://ng.neurology.org/content/5/3/e329.full.html\#\#otherarticles

This article, along with others on similar topics, appears in the following collection(s):

\section{All Genetics}

http://ng.neurology.org//cgi/collection/all_genetics

Information about reproducing this article in parts (figures,tables) or in its entirety can be found online at:

http://ng.neurology.org/misc/about.xhtml\#permissions

Information about ordering reprints can be found online: http://ng.neurology.org/misc/addir.xhtml\#reprintsus

Neurol Genet is an official journal of the American Academy of Neurology. Published since April 2015, it is an open-access, online-only, continuous publication journal. Copyright Copyright ( 2019 The Author(s). Published by Wolters Kluwer Health, Inc. on behalf of the American Academy of Neurology.. All rights reserved. Online ISSN: 2376-7839.

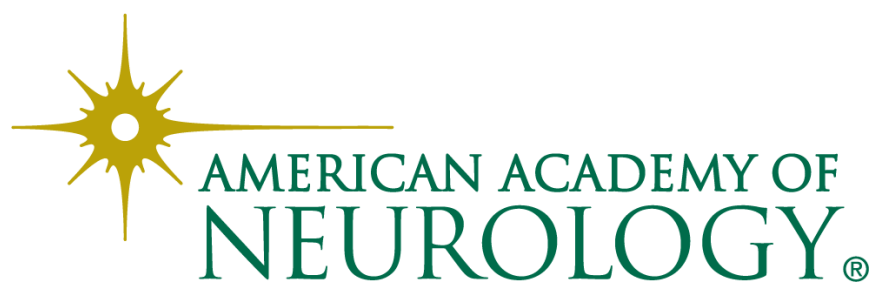

